\title{
Short communication: Genetic relationships among daily energy balance, feed intake, body condition score, and fat to protein ratio of milk in dairy cows
}

\author{
N. Buttchereit, ${ }^{* 1}$ E. Stamer, $†$ W. Junge,${ }^{*}$ and G. Thaller ${ }^{\star}$ \\ *Institute of Animal Breeding and Husbandry, Christian-Albrechts-University, D-24118 Kiel, Germany \\ †TiDa GmbH, D-24259 Westensee, Germany
}

\begin{abstract}
Postpartum energy status is critically important to health and fertility, and it remains a major task to find suitable indicator traits for energy balance. Therefore, genetic parameters for daily energy balance (EB) and dry matter intake (DMI), weekly milk fat to protein ratio (FPR), and monthly body condition score (BCS) were estimated using random regression on data collected from 682 Holstein-Friesian primiparous cows recorded between lactation d 11 to 180. Average energy-corrected milk (ECM), EB, DMI, BCS, and FPR were $32.0 \mathrm{~kg}, 9.6 \mathrm{MJ}$ of $\mathrm{NE}_{\mathrm{L}}, 20.3 \mathrm{~kg}, 2.95$, and 1.12, respectively. Heritability estimates for EB, DMI, BCS, and FPR ranged from 0.03 to $0.13,0.04$ to 0.19 , 0.34 to 0.59 , and 0.20 to 0.54 . Fat to protein ratio was a more valid measure for EB in early lactation than DMI, BCS, or single milk components. Correlations between FPR and EB were highest at the beginning of lactation [genetic correlation $\left(\mathrm{r}_{\mathrm{g}}\right)=-0.62$ at days in milk (DIM) 15] and decreased toward zero. Dry matter intake was the trait most closely correlated with EB in mid lactation $\left(\mathrm{r}_{\mathrm{g}}=0.73\right.$ at DIM 120 and 150). Energy balance in early lactation was negatively correlated to EB in mid lactation. The same applied to DMI. Genetic correlations between FPR across lactation stages were all positive; the lowest genetic correlation (0.55) was estimated between the beginning of lactation and early mid lactation. Hence, to improve EB at the beginning of lactation, EB and indicator traits need to be recorded in early lactation. We concluded that FPR is an adequate indicator for EB during the energy deficit phase. Genetic correlations of FPR with ECM, fat percentage, and protein percentage showed that a reduction of FPR in early lactation would have a slightly negative effect on ECM, whereas milk composition would change in a desirable manner.
\end{abstract}

Received April 30, 2010.

Accepted November 29, 2010.

${ }^{1}$ Corresponding author: nbuttchereit@tierzucht.uni-kiel.de
Key words: energy balance, fat to protein ratio, genetic parameter

\section{Short Communication}

In the past, selection mainly aimed to improve milk yield, ignoring the fact that this also increases the negative energy balance (Veerkamp, 1998). Milk yield and DMI are positively correlated, but the correlated response in DMI cannot compensate for the increased energy requirements, especially in early lactation (Ingvartsen and Andersen, 2000). Body reserves need to be mobilized to counterbalance the extra nutrient demand for milk synthesis (Veerkamp and Koenen, 1999). If the resulting metabolic challenge cannot be met, cows are metabolically stressed (Pryce and Løvendahl, 1999). Reproductive and immune processes are downregulated to ensure galactopoiesis, because production and nonproduction traits are linked through a common pool of available energy (Collard et al., 2000). Therefore, the increase in milk yield is accompanied by an increased occurrence of health and fertility problems worldwide. Future breeding goals should be broadened to include traits related to metabolic stability, such as measures of DMI, BCS, or milk fat to protein ratio (FPR) (Grieve et al., 1986; Veerkamp and Koenen, 1999). Daily energy balance (EB) itself may be the best indicator of metabolic load (Coffey et al., 2001), but measurements are too costly and difficult to be applied in practice. VillaGodoy et al. (1988) pointed out that variation in EB is largely explained by DMI. Other authors highlighted the critical importance of BCS (e.g., Oikonomou et al., 2008), as a decline in BCS is evidence of tissue mobilization to compensate for a negative EB (Bauman and Currie, 1980). Alternatively, milk composition could be used as an indirect selection criterion for EB (de Vries and Veerkamp, 2000; Friggens et al., 2007). The FPR has been suggested as a potential indicator of energy balance (Grieve et al., 1986; Heuer et al., 2000). Buttchereit et al. (2010) estimated a correlation between cow effects for FPR and EB of -0.43 for DIM 15, but the genetic relationship between FPR and EB has not been investigated to date. 
Table 1. Descriptive statistics of the recorded traits (first lactation, DIM 11 to 180)

\begin{tabular}{lccccc}
\hline Trait & $\mathrm{n}$ & Mean & $\mathrm{SD}$ & Minimum & Maximum \\
\hline Age at first calving, mo & 682 & 26.9 & 2.4 & 21 & 38 \\
ECM, kg/d & 89,104 & 32.0 & 4.5 & 2.5 & 51.5 \\
Fat, \% & 12,939 & 3.62 & 0.61 & 1.22 & 8.68 \\
Protein, \% & 12,940 & 3.24 & 0.24 & 1.96 & 4.28 \\
Fat to protein ratio & 12,939 & 1.12 & 0.20 & 0.36 & 2.96 \\
Energy balance, MJ of $\mathrm{NE}_{\mathrm{L}} / \mathrm{d}$ & 48,899 & 9.6 & 34.5 & -117.7 & 177.5 \\
DMI, kg/d & 66,699 & 20.3 & 4.7 & 2.8 & 43.4 \\
BCS & 3,067 & 2.95 & 0.33 & 1.50 & 3.80 \\
BW, $\mathrm{kg}$ & 72,498 & 595 & 53 & 404 & 834 \\
\hline
\end{tabular}

To improve EB, it is important to determine which EB-related traits to measure at which lactation stage. This depends on explanatory power and heritability of such traits, as well as their genetic correlation with EB and milk yield over time. The objective of the current study was to examine genetic relationships among $\mathrm{EB}$, ECM, DMI, BCS, and FPR using random regression.

Data were collected from 682 Holstein-Friesian primiparous cows descending from 161 sires and 525 dams. Data were recorded between September 2005 and April 2009 on the dairy research farm Karkendamm (Germany) running a bull dam performance test. All Karkendamm bull dam candidates have to complete a test period under commercial conditions in a freestall barn with a rotary milking parlor until DIM 180. Nonqualified primiparous cows leave the herd afterward, resulting in a reduced number of strongly preselected animals with records after DIM 180. Therefore, only records between DIM 11 and DIM 180 were analyzed in the present study.

Cows were milked twice daily. Milk yield was automatically recorded at every milking. Milk composition was analyzed weekly based on samples collected from 2 consecutive milkings. Milk composition per day was obtained by weighing the daily analysis values with the respective milk yield. Energy-corrected milk was calculated according to Kirchgeßner (1997):

$$
\begin{gathered}
\operatorname{ECM}(\mathrm{kg})=(0.39 \times \text { fat } \%+0.24 \times \text { protein } \% \\
+0.17 \times \text { lactose } \%) \times \text { milk yield }(\mathrm{kg}) / 3.17
\end{gathered}
$$

Cows have been weighed after every milking since March 2006. Morning and evening BW were averaged to derive a daily value. Body condition was scored monthly by the same person using a 5 -point scale with 0.1 intervals.

Animals were fed a TMR ad libitum. Total mixed ration intake per day (TMI) was recorded for each animal via single feeding troughs equipped with a weighing unit and automatic cow identification. Because cows were generally housed separately during the first 10
DIM, no feed intake data were available for this period. Individual TMI data were deleted for the first and last day with TMI information and for cows separated for insemination or pregnancy testing. Values obtained for fresh TMI were discarded if they were among the 0.05 percentage highest or 0.05 percentage lowest values, resulting in a range of fresh TMI between 4.2 and 90.6 $\mathrm{kg}$. Average $\mathrm{NE}_{\mathrm{L}}$ of TMR was $7.1 \mathrm{MJ} / \mathrm{kg}$ of DM. Fixed amounts of concentrates were delivered at concentrate feeders.

Energy balance was calculated as the difference between energy intake and estimated energy requirements for milk output and maintenance as described by Buttchereit et al. (2010).

Animals were excluded from the analysis if number of observations per trait and cow across the entire period was $<4$. For BCS, a minimum of only 2 observations was considered, because this trait was recorded less frequently than the others. A summary of the data is given in Table 1.

Data were analyzed using random regression models considering the fixed effects test-day, age at first calving, and stage of lactation. Age at first calving was divided into 5 classes (21 to $25,26,27,28$, and 29 to $38 \mathrm{mo}$ ). The general lactation curve was modeled by the function according to Ali and Schaeffer (1987), and random regression coefficients for permanent and additive genetic effects were modeled applying Legendre polynomials of 2 degrees:

$$
\begin{aligned}
y_{i j k l m}= & T D_{i}+A F C_{j}+\sum_{n=1}^{4} b_{n} x_{i j k l m n}(d)+\sum_{n=0}^{2} p_{k n} x_{i j k l m n}(d) \\
& +\sum_{n=0}^{2} a_{l n} x_{i j k l m n}(d)+e_{i j k l m},
\end{aligned}
$$

where $y_{i j k l m}=$ observation of ECM, fat percentage (fat $\%$ ), protein percentage (protein \%), FPR, EB, DMI, or BCS; $T D_{i}=$ fixed effect of test-day $(i=1$ to 1,305 for $\mathrm{ECM}, i=1$ to 186 for fat \%, protein \%, and FPR, $i=$ 1 to 942 for EB, $i=1$ to 1,170 for DMI, and $i=1$ to 44 for $\mathrm{BCS}) ; A F C_{j}=$ fixed effect of age at first calving 
$(j=1$ to 5$) ; b_{n}=$ fixed regression coefficients on lactation day $d$ with $x_{i j k l m 1}(d)=d / 190, x_{i j k l m 2}(d)=(d / 190)^{2}$, $x_{i j k l m 3}(d)=\ln (190 / d)$, and $x_{i j k l m 4}(d)=[\ln (190 / d)]^{2} ; p_{k}$ $=$ random regression coefficients for the permanent environmental effect of primiparous cow $k$; and $a_{l}=$ random regression coefficients for the additive genetic effect of the lth animal with $x_{i j k l m 0}(d)=1, x_{i j k l m 1}(d)=$ $-1+2(d-11 / 180-11)$, and $x_{i j k l m 2}(d)=1.5[-1+2(d$ $-11 / 180-11)]^{2}-0.5(k=1$ to 668 for ECM, $k=1$ to 627 for fat $\%$, protein $\%$, and FPR, $k=1$ to 526 for $\mathrm{EB}, k=1$ to 598 for DMI, and $k=1$ to 603 for BCS, $l$ $=1$ to 4,293$)$; and $e_{i j k l m}=$ random error.

Residual errors were expected to have heterogeneous variances, so the first 180 DIM were split into 6 measurement error classes. Within these classes, residual errors were assumed to be homogeneous. Residual covariances were assumed to be zero. Variance components were estimated for univariate and bivariate animal models by REML using the software package ASReml 3.0 (Gilmour et al., 2009). Standard errors for heritability estimates and genetic correlations were calculated with the methodology proposed by Fischer et al. (2004).

Age at first calving had a significant influence on all traits studied. A late calving ( $>28 \mathrm{mo}$ ) was detrimental to EB. Cows that were older at the time of successful insemination were able to gain greater BW before calving, but this might have had negative effects on their appetite and, consequently, have led to an increased energy deficit. Concerning FPR, primiparous cows should calve neither too young nor too old. The lowest least squares means for FPR were found for primiparous cows with a calving age between 27 and 28 mo.

Figure 1 depicts heritability estimates of EB, FPR, BCS, and DMI across DIM. A common pattern throughout lactation was observed for EB and DMI, indicating that EB as defined in this study is highly affected by energy intake. Both EB and DMI were genetically most strongly determined at DIM 15 . Heritability estimates of $\mathrm{EB}$ were in the range of 0.03 to 0.13 . The heritability of DMI was on the same level as for EB $\left(\mathrm{h}^{2}\right.$ $=0.04$ to 0.19$)$. Heritability estimates of FPR ranged between 0.20 and 0.54 , with the highest values found at the beginning of lactation and at the end of the data recording period. The trajectory was similar to the heritability of fat $\%\left(\mathrm{~h}^{2}=0.29\right.$ to 0.54$)$, whereas heritability estimates of protein $\%$ decreased from 0.61 (DIM 15) to 0.27 (DIM 180) and, therefore, showed a completely different pattern (data not shown). Heritability of BCS decreased from 0.59 at DIM 15 to values below 0.4 from DIM 120 onward. Standard errors for heritability estimates ranged between 0.04 and 0.15 . All heritability estimates were statistically significant $(P$ $<0.05$ ), except for DMI (from DIM 45 onwards) and EB.

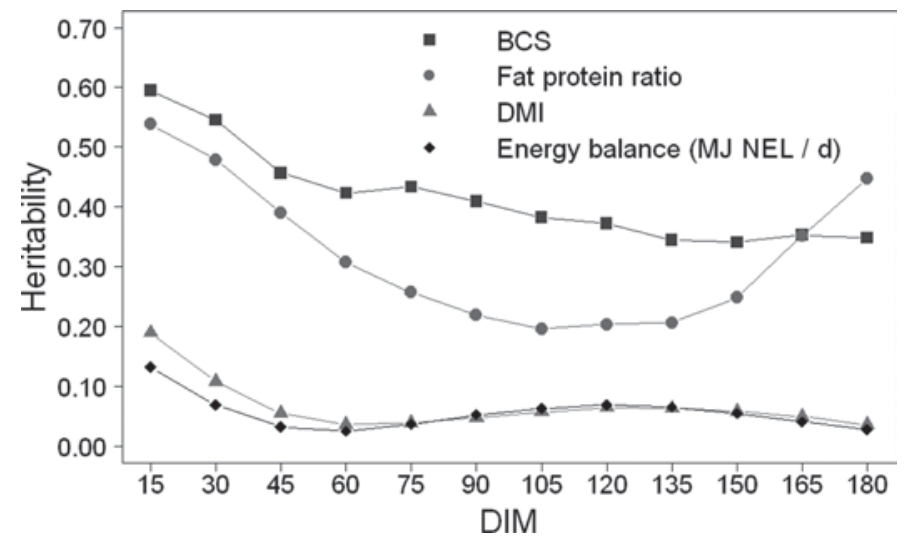

Figure 1. Estimated heritabilities of energy balance, DMI, fat to protein ratio, and BCS across the first 180 DIM.

Genetic correlations between FPR, EB, ECM, DMI, BCS, fat \%, and protein \% along DIM 15 to 180 are presented in Table 2. Most of the estimates were not significantly different from zero $(P>0.05)$ because of large standard errors. Nevertheless, the results provide some interesting aspects of EB and relationships between and among indicator traits.

With respect to its major determinants, EB was more closely correlated with ECM [genetic correlation $\left(\mathbf{r}_{\mathrm{g}}\right)=$ -0.57 at DIM $15 ; P<0.05]$ than with DMI in early lactation. Genetic correlations between ECM and EB were all negative until DIM 60. Exclusive breeding for milk yield will therefore intensify the energy deficit postpartum. Dry matter intake cannot be recommended as an early EB indicator, but it turned out to be the most suitable indicator for the energy status during mid lactation $\left(\mathrm{r}_{\mathrm{g}}=0.73\right.$ at DIM 120 and $\left.150 ; P<0.05\right)$. Milk composition traits were all more closely correlated to EB than DMI in early lactation and represent promising traits to select indirectly against increasing energy deficits postpartum. Postpartum lipolysis increases fat $\%$, whereas protein \% decreases if EB is negative (Fulkerson et al., 2001; Kessel et al., 2008). At DIM 15, a correlation of -0.51 was estimated between fat $\%$ and EB $(P<0.05)$. The correlation between protein $\%$ and EB was slightly higher $\left(\mathrm{r}_{\mathrm{g}}=0.53\right.$ at DIM 15$)$ but not significant $(P>0.05)$. Fat to protein ratio reflects both properties and showed the strongest relationship with EB during the critical early stage of lactation, which is in agreement with findings of Grieve et al. (1986), who concluded that the ratio of milk fat and protein content was a better predictor of energy status than either component by itself. The negative correlations between FPR and EB in this study were highest in the beginning of lactation $\left(\mathrm{r}_{\mathrm{g}}=-0.62\right.$ at DIM $15 ; P$ $<0.05)$ and decreased toward zero at the end of the data recording period. Corresponding estimates were 
Table 2. Genetic correlations between ECM, energy balance (EB), DMI, fat to protein ratio (FPR), fat percentage (fat \%), protein percentage (protein \%), and BCS for 9 different lactation stages (DIM 15 to 180)

\begin{tabular}{|c|c|c|c|c|c|c|c|c|c|}
\hline \multirow[b]{2}{*}{ Trait } & \multicolumn{9}{|c|}{ DIM } \\
\hline & 15 & 30 & 45 & 60 & 75 & 90 & 120 & 150 & 180 \\
\hline EB-DMI & 0.44 & 0.25 & 0.02 & -0.10 & 0.08 & 0.42 & $0.73^{*}$ & $0.73^{*}$ & 0.59 \\
\hline EB-FPR & $-0.62^{*}$ & -0.59 & -0.54 & -0.50 & -0.45 & -0.13 & -0.05 & 0.01 & 0.02 \\
\hline $\mathrm{EB}$-fat $\%$ & $-0.51^{*}$ & -0.37 & -0.19 & -0.03 & 0.03 & 0.03 & -0.07 & -0.20 & -0.45 \\
\hline EB-protein \% & 0.53 & 0.45 & 0.30 & 0.06 & -0.05 & -0.04 & 0.06 & 0.14 & 0.15 \\
\hline DMI-FPR & $-0.54^{*}$ & $-0.48^{*}$ & -0.34 & -0.08 & 0.19 & 0.31 & 0.23 & 0.05 & -0.18 \\
\hline DMI-fat $\%$ & $-0.44^{*}$ & -0.38 & -0.26 & -0.08 & 0.07 & 0.11 & 0.01 & -0.16 & -0.38 \\
\hline DMI-protein \% & 0.34 & 0.22 & 0.05 & -0.14 & -0.25 & -0.28 & -0.28 & -0.33 & -0.53 \\
\hline DMI-BCS & 0.14 & 0.10 & 0.03 & -0.06 & -0.14 & -0.19 & -0.26 & -0.36 & -0.47 \\
\hline FPR-ECM & 0.34 & 0.20 & 0.02 & -0.19 & -0.35 & -0.38 & -0.23 & -0.05 & 0.14 \\
\hline FPR-fat $\%$ & $0.90^{*}$ & $0.88^{*}$ & $0.85^{*}$ & $0.84^{*}$ & $0.84^{*}$ & $0.86^{*}$ & $0.91 *$ & $0.95^{*}$ & $0.97^{*}$ \\
\hline FPR-protein $\%$ & $-0.51^{*}$ & $-0.41^{*}$ & $-0.29^{*}$ & -0.17 & -0.03 & 0.09 & 0.29 & $0.45^{*}$ & $0.53^{*}$ \\
\hline
\end{tabular}

$* P<0.05$.

reported by Reist et al. (2002) with a phenotypic correlation of -0.5 from wk 1 to 10 and by Buttchereit et al. (2010) with correlations between cow effects ranging from $\mathrm{r}_{\mathrm{c}}=-0.43$ (DIM 15) to -0.14 (DIM 180). Fat to protein ratio was also a better predictor for EB than BCS until DIM 90 and this was true, even if monthly instead of weekly FPR measurements were used (data not shown).

Fat to protein ratio appears to be a well-suited indicator for EB during the critical early stage of lactation but it has to be taken into account that selection on decreasing FPR would affect milk yield and composition as well. Fat to protein ratio and ECM were positively, albeit not significantly, correlated at the beginning of lactation. Meinert et al. (1989) reported a genetic correlation of -0.15 for protein to fat ratio and milk yield from DIM 40 to 100. The genetic correlations between FPR and fat \% were highly positive throughout lactation $\left(\mathrm{r}_{\mathrm{g}}=0.84\right.$ to $\left.0.97 ; P<0.05\right)$. Fat to protein ratio and protein $\%$ were less strongly correlated. A moderate correlation of $-0.51(P<0.05)$ was found at DIM 15 and correlations rapidly decreased toward 0 until DIM 75. Vos and Groen (1998) stated that inclusion of FPR in breeding goals would cause a lower fat $\%$ and slightly higher protein \%. According to the present results, this applies only at the beginning of lactation, because correlations between FPR and protein \% switch from negative to positive toward mid lactation $\left(\mathrm{r}_{\mathrm{g}}=0.53\right.$ at DIM 180; $P<0.05$ ). This is a consequence of the increase of the correlation between fat $\%$ and protein $\%(-0.11$ at DIM 15 to 0.67 at DIM 180; $P<0.05$; data not shown). The correlation of FPR with DMI at the beginning of lactation is such that selection for a lower FPR would result in an increased DMI. This is in agreement with findings of Heuer et al. (2000).

As already stated, DMI was found to be a proper EB indicator only in mid lactation. Further correlations of DMI with traits other than EB support the need to differentiate between lactation stages. There is close consensus regarding the genetic correlations reported between yield and DMI that range from 0.46 to 0.65 on the lactation level (Veerkamp, 1998). Using random regression, however, Veerkamp and Thompson (1999) found that DMI during early lactation was negatively correlated with milk yield. In this study, correlations between ECM and DMI were close to zero in early lactation $\left(\mathrm{r}_{\mathrm{g}}=-0.01\right.$ at DIM 15), and later on increased to a maximum of 0.63 (DIM 180) without, however, attaining statistical significance $(P>0.05)$. Lee et al. (1992) also showed that the correlation between milk yield and feed intake is less pronounced in early compared with later periods. Selection for DMI would also have an influence on milk composition. A moderate negative correlation between DMI and fat \% was found at DIM $15\left(\mathrm{r}_{\mathrm{g}}=-0.44 ; P<0.05\right)$.

Fat to protein ratio and DMI have so far been discussed as possible indicator traits useful to include EB in breeding goals. Both traits are influenced by various biological processes (e.g., Ingvartsen and Andersen, 2000) and might have a different genetic background across lactation stages. Genetic relationships of EB, DMI, and FPR were therefore estimated between different days of lactation to evaluate the optimal frequency and time points of recording (Table 3). Genetic correlations between daily EB estimates across lactation ranged from -0.64 (DIM 15-120) to 0.82 (DIM 
Table 3. Genetic correlations across DIM (15 to 180 DIM) for energy balance (EB), DMI, and fat to protein ratio (FPR)

\begin{tabular}{lrcc}
\hline & \multicolumn{3}{c}{ DIM } \\
\cline { 2 - 4 } Item & 15 & 60 & 120 \\
\hline EB & 0.25 & & \\
60 & -0.64 & 0.82 & \\
120 & -0.43 & 0.21 & 0.67 \\
180 & & & \\
DMI & 0.54 & & \\
60 & -0.51 & 0.50 & $0.83^{*}$ \\
120 & -0.55 & 0.15 & \\
180 & & & \\
FPR & $0.93^{*}$ & $0.55^{*}$ & $0.92^{*}$ \\
60 & $0.59^{*}$ & $0.83^{*}$ & \\
120 & $0.70^{*}$ &
\end{tabular}

$* P<0.05$.

60-120). It has to be noted, that these estimates were not statistically different from zero because of the small sample size. However, they indicate a potentially negative association between energy balance observations in very early and mid lactation. The results suggest that primiparous cows exhibiting a severe energy deficit in the beginning of lactation later successfully compensate for the deficiency resulting in an EB above average in mid lactation. Therefore, these animals swing from one extreme to the other. Conversely, primiparous cows that have a less negative EB in early lactation are likely to have a more balanced metabolic status. Genetic correlations between DMI measurements ranged from -0.55 (between DIM 15 and $180 ; P>0.05$ ) to 0.83 (between DIM 120 and 180; $P<0.05$ ). The results imply that EB and DMI are probably regulated by different genes in early and mid lactation. Improvement of DMI over the whole lactation would require measurements throughout all lactation stages.

Genetic correlations among FPR measurements across lactation stages were all positive and significant $(P<0.05)$, ranging from 0.55 (between DIM 60 and 120) to 0.93 (between DIM 15 and 60). Correlations generally decreased with increased time intervals between the observations, but FPR in early lactation and late mid lactation were more strongly correlated than FPR in early lactation and FPR around DIM 120. Therefore, observations for FPR around DIM 120 have the lowest predictive value, when the objective is to reduce the FPR in early lactation for improving the energy status.

It can be concluded that continued selection for high milk production will lead to a further increase in the postpartum energy deficit, unless EB is directly or indirectly included in breeding programs with appropriate economic weights. Improvement of the negative EB at the beginning of lactation would require records of $\mathrm{EB}$ in the energy deficit phase, because EB in early lactation and mid lactation are genetically different traits. Fat to protein ratio turned out to be an adequate EB indicator trait at the beginning of lactation; DMI and BCS were less suited to minimize early lactation metabolic load. Furthermore, FPR was a more valid measure of EB than were single milk components. Genetic correlations of FPR with ECM, fat percentage, and protein percentage showed that a reduction of FPR in early lactation would have a slightly negative effect on ECM, but the effect on milk composition would be a positive one. Clearly, EB is of major interest in future breeding programs and, based on the results of this study, FPR has to be considered as the most appropriate indicator. Further studies using more comprehensive data sets should be envisaged to further improve knowledge about the genetics of energy balance traits in early lactating cows.

\section{ACKNOWLEDGMENTS}

We gratefully acknowledge the German Federal Ministry of Education and Research (project FUGATO-plus MeGA-M, grant no. 0315131B) and the Förderverein Biotechnologieforschung, Bonn, Germany, for financial support.

\section{REFERENCES}

Ali, T. E., and L. R. Schaeffer. 1987. Accounting for covariances among test day milk yields in dairy cows. Can. J. Anim. Sci. 67:637-644.

Bauman, D. E., and W. B. Currie. 1980. Partitioning of nutrients during pregnancy and lactation: A review of mechanisms involving homeostasis and homeorhesis. J. Dairy Sci. 63:1514-1529.

Buttchereit, N., E. Stamer, W. Junge, and G. Thaller. 2010. Evaluation of five lactation curve models fitted for fat-protein ratio of milk and daily energy balance. J. Dairy Sci. 93:1702-1712.

Coffey, M. P., G. C. Emmans, and S. Brotherstone. 2001. Genetic evaluation of dairy bulls for energy balance traits using random regression. Anim. Sci. 73:29-40.

Collard, B. L., P. J. Boettcher, J. C. M. Dekkers, D. Petitclerc, and L. R. Schaeffer. 2000. Relationships between energy balance and health traits of dairy cattle in early lactation. J. Dairy Sci. 83:2683-2690.

de Vries, M. J., and R. F. Veerkamp. 2000. Energy balance of dairy cattle in relation to milk production variables and fertility. J. Dairy Sci. 83:62-69.

Fischer, T. M., A. R. Gilmour, and J. H. J. van der Werf. 2004. Computing approximate standard errors for genetic parameters derived from random regression models fitted by average information REML. Genet. Sel. Evol. 36:363-369.

Friggens, N. C., C. Ridder, and P. Lovendahl. 2007. On the use of milk composition measures to predict the energy balance of dairy cows. J. Dairy Sci. 90:5453-5467.

Fulkerson, W. J., J. Wilkins, R. C. Dobos, G. M. Hough, M. E. Goddard, and T. Davison. 2001. Reproductive performance in Holstein-Friesian cows in relation to genetic merit and level of feeding when grazing pasture. Anim. Sci. 73:397-406.

Gilmour, A. R., B. J. Gogel, B. R. Cullis, and R. Thompson. 2009. ASReml User Guide. Release 3.0. VSN International Ltd., Hemel Hempstead, UK. 
Grieve, D. G., S. Korver, Y. S. Rijpkema, and G. Hof. 1986. Relationship between milk composition and some nutritional parameters in early lactation. Livest. Prod. Sci. 14:239-254.

Heuer, C., W. M. Van Straalen, Y. H. Schukken, A. Dirkzwager, and J. P. T. M. Noordhuizen. 2000. Prediction of energy balance in a high yielding dairy herd in early lactation: Model development and precision. Livest. Prod. Sci. 65:91-105.

Ingvartsen, K. L., and J. B. Andersen. 2000. Integration of metabolism and intake regulation: A review focusing on periparturient animals. J. Dairy Sci. 83:1573-1597.

Kessel, S., M. Stroehl, H. H. Meyer, S. Hiss, H. Sauerwein, F. J. Schwarz, and R. M. Bruckmaier. 2008. Individual variability in physiological adaptation to metabolic stress during early lactation in dairy cows kept under equal conditions. J. Anim. Sci. 86:2903-2912.

Kirchgeßner, M. 1997. Tierernährung. Vol. 10. DLG-Verlag, Frankfurt a. Main, Germany.

Lee, A. J., D. A. Boichard, A. J. McAllister, C. Y. Lin, K. Nadarajah, T. R. Batra, G. L. Roy, and J. A. Vesely. 1992. Genetics of growth, feed intake, and milk yield in Holstein cattle. J. Dairy Sci. 75:3145-3154.

Meinert, T. R., S. Korver, and J. A. M. van Arendonk. 1989. Parameter estimation of milk yield and composition for 305 days and peak production. J. Dairy Sci. 72:1534-1539.

Oikonomou, G., G. E. Valergakis, G. Arsenos, N. Roubies, and G. Banos. 2008. Genetic profile of body energy and blood metabolic traits across lactation in primiparous Holstein cows. J. Dairy Sci. 91:2814-2822.

Pryce, J. E., and P. Løvendahl. 1999. Options to reduce vulnerability to metabolic stress by genetic selection. Pages 119-127 in Meta- bolic Stress in Dairy Cows. J. D. Oldham, G. Simm, A. F. Groen, B. L. Nielsen, J. E. Pryce and T. L. J. Lawrence, ed. Occasional publication No. 24. Br. Soc. Anim. Sci., Edinburgh, UK.

Reist, M., D. Erdin, D. von Euw, K. Tschuemperlin, H. Leuenberger, Y. Chilliard, H. M. Hammon, C. Morel, C. Philipona, Y. Zbinden, N. Kuenzi, and J. W. Blum. 2002. Estimation of energy balance at the individual and herd level using blood and milk traits in highyielding dairy cows. J. Dairy Sci. 85:3314-3327.

Veerkamp, R. F. 1998. Selection for economic efficiency of dairy cattle using information on live weight and feed intake: A review. J. Dairy Sci. 81:1109-1119.

Veerkamp, R. F., and E. P. C. Koenen. 1999. Genetics of food intake, live weight, condition score and energy balance. Pages 63-73 in Metabolic Stress in Dairy Cows. J. D. Oldham, G. Simm, A. F. Groen, B. L. Nielsen, J. E. Pryce and T. L. J. Lawrence, ed. Occasional publication No. 24. Br. Soc. Anim. Sci., Edinburgh, UK.

Veerkamp, R. F., and R. Thompson. 1999. Multi-trait covariance functions to estimate genetic correlations between milk yield, drymatter intake and live weight during lactation. Pages 147-151 in Metabolic Stress in Dairy Cows. J. D. Oldham, G. Simm, A. F. Groen, B. L. Nielsen, J. E. Pryce and T. L. J. Lawrence, ed. Occasional publication No. 24. Br. Soc. Anim. Sci., Edinburgh, UK.

Villa-Godoy, A., T. L. Hughes, R. S. Emery, L. T. Chapin, and R. L. Fogwell. 1988. Association between energy balance and luteal function in lactating dairy cows. J. Dairy Sci. 71:1063-1072.

Vos, H., and A. F. Groen. 1998. Altering milk protein/fat-ratio: Results of a selection experiment in dairy cattle. Livest. Prod. Sci. $53: 49-55$. 